\title{
DEN FÆNOMENOLOGISKE METODE I MUSEOLOGISK FORSKNING
}

Bjarne Sode Funch

Introspective observation is what we have

to rely on first and foremost and always.

William James, 1890, I: 185
Fænomenologi er læren om menneskets bevidsthedsliv. I den grundlæggende udforskning af bevidsthedslivet anvendes den fænomenologiske metode som består af en række strategier til iagttagelse og beskrivelse af det der træder frem i bevidstheden. Da livets primære fremtrædelsesform er dets aktualisering i bevidstheden, har fænomenologisk forskning en central position inden for den psykologiske videnskab. Men hvad har fænomenologi og museologi med hinanden at gøre?

Inden for museumsvirksomhed som inden for enhver anden virksomhed, spiller den menneskelige faktor en større rolle end man almindeligvis tilkender den. Museale samlinger er skabt af mennesker. Mennesker med særlige interesser, viden og trang til at bevare og formidle. Ønsker man at forstå disse basale former for menneskelig virksomhed med henblik på at forbedre og udvikle det arbejde der varetages af et museum, må man søge kendskab til de bevidsthedsfænomener som er knyttet til de pågældende aktiviteter.

Principper for indsamling, bevaring og formidling bygger oftest på fagspecifik viden og løse formodninger. Faglig viden om det kultur- eller naturområde museet forvalter og løse formodninger om de psykologiske forhold der hersker mellem mennesker og deres naturgivne og kulturelle omgivelser samt deres historiske fortid. Museumsvirksomhed der sætter mennesket i centrum kan ikke nøjes med psykologiske formodninger, men må gøre klart hvilken betydning og funktion museet har for det enkelte menneske. Kun gennem psykologisk forskning er det muligt at få kendskab til de forhold i den menneskelige psyke og eksistens der gør museet til en kulturel institution i samfundet. Den fænomenologisk psykologiske forskning giver direkte adgang til den bevidsthedsverden som i vor tid er knyttet til museet som institution, og den fænomenologiske metode er derfor en af de vigtigste forskningsstrategier når man ønsker indblik i de psykologiske forhold der gør museet personligt vedkommende og gør det muligt at tilrettelægge indsamling og formidling på en måde der bidrager til individuel og kulturel integritet. 
EKSEMPEL PÅ FÆNOMENOLOGISK FORSKNING

Et eksempel kan illustrere fænomenologiens anvendelse inden for den museologiske forskning.

På kunstmuseerne har man gennem generationer introduceret publikum til billedkunst på grundlag af kunsthistoriske principper. Samlingerne er præsenteret i kronologiske og stilorienterede ophængninger. I kataloger, introducerende tekster og rundvisninger refereres til kunsthistoriske forhold som stiludvikling, billedkomposition, ikonografi samt kulturelle og biografiske forhold. Velvidende at den slags information sjældent fremmer den personlige og emotionelle oplevelse der almindeligvis forbindes med kunstoplevelse.

For at få et indblik i kunstintroduktionens betydning for kunstoplevelse, blev der i juni 2002 gennemført et forskningsprojekt på Esbjerg Kunstmuseum.

Et kunstværk, Blutspiegel (1994) af Christian Lemmerz blev udstillet $\mathrm{i}$ et separat rum. Ved indgangen til udstillingen blev publikum tilbudt fire forskellige introduktioner til kunstværket: en kunsthistorisk hvor to kunsthistorikere diskuterer værket, en lyrisk hvor forfatteren Peter Laugesen læser en tekst han har skrevet om Lemmerz kreativitet og værk, en musikalsk hvor komponisten og musikeren Frederik Søgaard spiller et stykke musik der er komponeret til Blutspiegel og endelig en spontan beretning af en syvårig dreng der ser værket.

Undersøgelsen var tilrettelagt på den måde at et lille antal tilfældigt udvalgte personer i forskellig alder og med forskellige baggrund, blev bedt om at vælge og lytte til en af de fire introduktioner inden de gik ind for at se kunstværket. Umiddelbart efter blev de inter- viewet med henblik på at få afdækket hvilke forestillinger, tanker og følelser de havde mens de lyttede til introduktionen og hvordan de efterfølgende oplevede det pågældende kunstværk.

Disse undersøgelser (Funch 2003) blev gennemført $i$ et forsøg på at få et indblik i den bevidsthedsverden som opstår når en person bliver introduceret til et kunstværk på en særlig måde. Ved at få indblik i de forestillinger, følelser og tanker som knytter sig til en bestemt formidlingsform får vi grundlag for at vurdere det personlige udbytte. En enkel undersøgelsesrække giver ikke basis for at udlede de nødvendige og tilstrækkelige principper for hvorledes publikum bedst introduceres til et billedkunstnerisk værk, men de fænomenologiske iagttagelser åbner for hvad der sker i den menneskelige bevidsthed og kan bidrage til udvikling af en formidlingsstrategi der er i overensstemmelse med museets målsætning.

Undersøgelsens datamateriale blev indsamlet efter de fænomenologiske principper for psykologisk udforskning af bevidsthedslivet som i det følgende beskrives.

\section{PSYKOLOGISK FæNOMENOLOGIS HISTORIE}

Bevidsthedslivet har altid tiltrukket menneskers opmærksomhed. Ikke blot særlige fænomener som drømme, hallucinationer og andre specielle fænomener, men også den almindelige bevidsthed har tiltrukket opmærksomhed. Augustin (1991) som i det fjerde århundrede beskrev sit eget liv i bogen Bekendelser, var dybt fascineret af bevidsthedsfænomener knyttet til erindringen. Han undrer sig blandt andet over at man kan forestille sig havets bølger, bjergenes høje tinder og himlens stjerner uden samtidig at se dem. Man skal således ikke 
lede længe i tidlige filosofiske, religiøse og litterære skrifter før man støder på fænomenologiske beskrivelser.

Den tyske filosof og psykolog Franz Brentano er en af de første der gør sig overvejelser om fænomenologisk iagttagelse som metode, og især hans bog Psychologie vom empirischen Standpunkt fra 1874 får stor betydning for metodens anvendelse inden for psykologisk forskning. Flere tyske psykologer som for eksempel Alexius Meinong og Carl Stumpf fulgte hans forelæsninger $\mathrm{i}$ Wien og anvendte hans principper i deres egen forskning. Kurt Koffka og Wolfgang Köhler, som begge var elever af Stumpf, blev fremtrædende repræsentanter for den gestaltpsykologiske skole hvor den fænomenologiske beskrivelse er en del af den eksperimentelle metode. Da de på grund af nazismen måtte flygte fra Tyskland bragte de den fænomenologiske metode ind $\mathrm{i}$ amerikansk psykologi hvor den især fik betydning for den humanistiske og eksistentielle psykologi med repræsentanter som Carl Rogers, Abraham Maslow og Rollo May. En betydning som tydeligt kan spores i amerikansk psykologi i dag.

Mens mange psykologer således flygtede til USA i 1930'erne forblev en af Brentanos filosofiske elever, Edmund Husserl og dennes assistent Martin Heidegger i Tyskland. Husserl var professor i Freiburg hvor han blev pensioneret i 1928. Han blev senere offer for den anti-semitiske lovgivning og blev slettet af listen over universitetsprofessorer i 1933. Han døde fem år senere i 1938. Heidegger som overtog Husserls lærestol i Freiburg var venligt stemt over for nazismen og fik af samme grund undervisningsforbud efter krigens afslutning. Han blev pensioneret i 1951 og døde i 1976. Især Heidegger fik afgørende betydning for en eksistentielt orienteret fænomeno- logi som voksede frem efter anden verdenskrig.

I Danmark som det eneste sted i Europa, forblev den fænomenologiske tradition uforstyrret af nazismen. Edgar Rubin som i 1911 til 1914 studerede hos G. H. Müller i Göttingen, fulgte under sit studieophold Husserls forelæsninger. Da han i 1922 blev professor og leder af instituttet for psykologi i København indførte han den fænomenologiske metode i det eksperimentelle arbejde. Han havde nære kontakter til de tyske gestaltpsykologer og hans fænomenologiske indsats blev kendt som Københavnerskolen. Hans elever og efterfølgere Edgar Tranekjær Rasmussen og Franz From er ligeledes begge kendte for deres fænomenologiske forskning, og traditionen er blevet fulgt op af blandt andre Martin Johansen, Ib Moustgaard og Torsten Ingemann Nielsen.

\section{BeVidsthedsstrøM}

Begrebet bevidsthed kan give indtryk af noget afgrænset og stabilt. Men bevidstheden i fænomenologisk perspektiv er tværtimod noget der er i konstant bevægelse og uafbrudt ændrer sig. Den amerikanske psykolog William James $(1892,159)$ beskriver det som en "bevidsthedsstrøm" (stream of consciousness), et begreb som senere skulle blive knyttet til en litterær genre med James Joyce som fremtrædende repræsentant. Det vil sige at indtryk, tanker, erindringer, følelser som udgør bevidstheden, strømmer igennem i evig forandring. Nye fænomener dukker op, andre forsvinder, nogle ændrer sig langsomt, andre opstår pludseligt for måske at forsvinde lige så hurtigt igen. Dette kaldes den spontane bevidsthed hvor fænomenerne fremtræder $\mathrm{i}$ bevidstheden uden at der samtidig er en bevidsthed om fænomenernes fremtrædelsesform. Kun gennem den 
refleksive bevidsthed er det muligt at rette opmærksomheden mod den spontane bevidsthedsstrøm og blive sig bevidst hvad der i et bestemt øjeblik er i bevidstheden. Med andre ord, den refleksive bevidsthed er i stand til at fokusere på en sekvens af den konstant strømmende bevidsthed og til så at sige fastholde et forløb som allerede findes i bevidstheden. Der er en uafbrudt samspil mellem den spontane og den refleksive bevidsthed på en sådan måde at vi sjældent bemærker hvornår henholdsvis den ene eller den anden bevidsthedsform er fremtrædende og dominerende.

Den fænomenologiske beskrivelse hænger snævert sammen med den refleksive bevidsthed. Når en person beskriver en oplevelse, sker det typisk ved at vedkommende genkalder sig noget der tidligere har manifesteret sig i bevidstheden. Den refleksive bevidsthed er således en forudsætning for en konceptualisering af det der træder frem i den spontane bevidsthedsstrøm. Metodisk udgør dette naturligvis et stort problem idet den ideelle fænomenologiske beskrivelse ville være en nøje gengivelse af bevidsthedsstrømmen inden for en given periode. Men det lader sig ikke gøre. For det første fordi bevidsthedens fremtrædelsesform ikke lader sig gengive - der findes ganske enkelt ikke et medie der på analog måde kan gengive hvad der foregår i den spontane bevidstheden. For det andet er det ikke bevidsthedsstrømmen som sådan der beskrives, men bevidsthedsstrømmen som den fastholdes af den refleksive bevidsthed. Med andre ord, det er ikke det levede liv der beskrives, men livet som det opleves eller genkaldes i den refleksive bevidsthed.

\section{Oplevelse}

Bevidstheden manifesterer sig som en bevidsthedsstrøm med døden som den endelige afslutning og en begyndelse som sandsynligvis finder sted på et tidspunkt i fosterstadiet. Antagelig afbrydes denne strøm af bevidsthedens fremtrædelsesformer hverken af søvn eller såkaldt bevidstløshed, men er en uafbrudt virksomhed hvor fravær af refleksiv bevidsthed betyder at der ingen hukommelse er. Under søvn fortsætter bevidstheden som drøm og kun i særlige tilfælde hvor den refleksive bevidsthed er aktiv, bliver det muligt at genkalde et drømmeforløb i erindringer. Men det sandsynlige er at drømmen er et uafbrudt forløb som ikke afsætter hukommelsesspor der er tilgængelige for jeg'et og derfor forbliver uerkendt.

Livsløbets "film" er fra en videnskabelig synsvinkel en uhåndterlig størrelse. Halvfjerds års uafbrudt bevidsthed med den kompleksitet og detaljerigdom som bevidstheden manifesterer sig med, er naturligvis på ingen måde mulig at registrere, beskrive og analysere. Derfor bliver "oplevelse" et centralt begreb inden for den fænomenologiske psykologi. En oplevelse er en sekvens af livsløbets bevidsthed. Et oplevelsesforløb er et kortere eller længere forløb der er afgrænset af oplevelsens intentionalitet. Enhver oplevelse er karakteriseret ved at være fokuseret på noget bestemt, det kan være et hændelsesforløb eller en overvejelse. Det kendes fra dagligdagen at bevidstheden uophørligt skifter fokus fra ét til noget andet, det vil sige at den ene oplevelse afløser den anden. En oplevelse defineres derfor som den bevidsthedssekvens hvori intentionaliteten forbliver den samme.

Begrebet oplevelse er inden for fænomenologien et neutralt begreb forstået på den måde 
at mennesket til enhver tid er i et oplevelsesforløb. Med andre ord, mennesket har hele tiden en oplevelse. Der er ikke tale om en begivenhed der gør et særligt indtryk som det er tilfældet, når begrebet oplevelse anvendes i daglig tale. Det er i denne sammenhæng værd at bemærke at den "oplevelseskultur" som karakteriserer visse formidlingsinitiativer på museerne intet har med fænomenologi at gøre.

\section{BeVidsthedsAspeKTER}

En oplevelse er en udelelig enhed. Det er naturligvis problematisk at bruge begrebet "enhed" til at karakterisere noget som ikke er fikseret, stabilt og klart afgrænset; men taget dette i betragtning manifesterer bevidstheden sig som en række oplevelser der hverken kan reduceres til noget mere essentielt eller opdeles i noget der er mindre end en oplevelse. Oplevelse er ganske enkelt bevidsthedens og livets aktualisering på et givet tidspunkt. Oplevelsen er en bevidsthedssekvens med en tidslig udstrækning fra nogle fà sekunder til flere minutter afhængig af intentionalitetens stabilitet. Oplevelsen er derfor en grundenhed i fænomenologisk psykologi og al fænomenologisk forskning tager udgangspunkt i denne grundenhed.

At oplevelsen er en grundenhed forhindrer ikke en analytisk opdeling af oplevelsen i forskellige bevidsthedsaspekter. Sådanne bevidsthedsaspekter optræder sjældent for ikke at sige aldrig som isolerede oplevelsesenheder og er derfor ikke af fænomenologisk natur. På den anden side kan en analytisk bestemmelse af oplevelsens aspekter anvendes i forbindelse med fænomenologisk analyse og beskrivelse af specifikke oplevelsesfænomener. Derved bliver det muligt at karakterisere den konkrete oplevelse, ikke blot ved oplevelsens tematiske ind- hold, men også ved de aspekter som konstituerer oplevelsen.

I et psykologisk perspektiv falder det naturligt at differentiere mellem de psykologiske grundfunktioner som psyken traditionelt tilskrives. Ikke på grund af traditionen, men først og fremmest fordi disse grundfunktioner hver især har deres egen psykologiske natur som ikke lader sig beskrive på anden måde end ved henvisning til deres bevidsthedsmæssige fremtrædelsesform. En oplevelse kan således konstitueres med både sanselige, imaginære, emotionelle, kognitive og intentionelle aspekter. Almindeligvis konstitueres en oplevelse af flere aspekter, men ikke nødvendigvis af alle de nævnte. Ét aspekt vil ofte være mere fremtrædende end andre, men vil sjældent stå alene.

Det sansemessige aspekt kan fremtræde i forskellige modaliteter som for eksempel et visuelt aspekt gennem synsindtryk eller et auditivt gennem høreindtryk. Flere forskellige modaliteter optræder ofte ved siden af hinanden og supplerer hinanden i den oplevelse de konstituerer. Sanseindtryk kendes gennem erfaring og ligesom de andre bevidsthedsaspekter har de deres egen fænomenologiske fremtrædelsesform der ikke yderligere kan beskrives eller differentieres uden at overskride det fænomenologisk givne.

Sanseindtryk er omgivelsernes aktualisering i bevidstheden. Der er således i princippet ikke forskel på den visuelle omverden og det visuelle indtryk af denne visuelle omverden. De er ét og samme, selv om der samtidig kan være en begrebslig aktualisering af den visuelle omverden som en materiel og permanent omverden som er uafhængig af den aktuelle sansning. Omverden og oplevelse kan således på et og samme tidspunkt være det samme og dog noget forskelligt.

Det imaginare aspekt er ofte vanskeligere at 
22 identificere end det sansemæssige dels fordi det aktualiseres i bevidstheden uden tilsvarende referencer til de aktuelle omgivelser og dels fordi det vanskeligt lader sig differentiere fra det sansede og det kognitive. Ofte beskrives forestillinger som visuelle forestillinger der ligner sanseindtryk, men det er kun i yderst sjældne tilfælde at en forestilling svarer til et sanseindtryk. Såkaldte eidetiske forestillinger som er ligeså tydelige og detaljerede som en direkte visuel perception er et sjældent fænomen. De fleste visuelle forestillinger har en visuel fremtrædelsesform som er ganske anderledes end visuel perception. En forestilling om en forestående rejse for eksempel manifesterer sig ikke blot i form af indre billeder, men i et mentalt medie som er så forskelligt fra det visuelt sansede at det konstituerer et selvstændigt bevidsthedsaspekt.

Det emotionelle aspekt er ligesom det sansemæssige og imaginære et selvstændigt aspekt med sin egen psykologiske natur og fænomenologiske fremtrædelsesform. Freud (1965, 309) siger $i$ en af sine forelæsninger til indføring i psykoanalysen at følelsen angst ikke behøver nærmere præsentation fordi "enhver af os har på et eller andet tidspunkt selv lært denne følelse eller rettere sagt: affekttilstand, at kende." Dette gælder det emotionelle liv i det hele taget. Alle kender det emotionelle gennem erfaring, men at definere eller blot forsøgsvis beskrive emotionernes formelt psykologiske fremtrædelsesform er vanskeligt. En følelse er en følelse og fænomenologisk er denne bestemmelse så klar at der ingen vanskeligheder er med at adskille det emotionelle fra for eksempel det sansede eller forestillede.

Det kognitive aspekt som her refererer til konceptuelle erkendelsesmæssige funktioner må ligesom de allerede nævnte aspekter henregnes til et særskilt mentalt medie med egne fænomenologiske karakteristika. Det kan være vanskeligt at differentiere mellem kognitive aspekter $\mathrm{i}$ henholdsvis den spontane og den refleksive bevidsthed fordi sidstnævnte er en ren kognitiv funktion. I den spontane bevidsthed optræder det kognitive aspekt primært som et identificerende element. Ser man for eksempel et hus så ser man et hus og ikke kun et arkitektonisk design i form og farve. Den kognitive tydning supplerer den visuelle fremtrædelsesform og de fremstår som en integreret helhed.

Endelig er der det intentionelle aspekt som er den rettethed der karakteriserer enhver oplevelse. Ligesom floden løber igennem landskabet mod havet, således løber bevidsthedsstrømmen også i en bestemt retning. Der kan ikke altid angives et endeligt mål, men alligevel vil enhver oplevelse være karakteriseret af et fokus som bevidstheden er rettet imod. I visse sjældne tilfælde vil oplevelsen være sit eget fokus, men oftest vil oplevelsens fokus række ud over det som allerede manifesteres ved de andre aspekter.

Den intentionelle funktion er et vigtigt redskab for jeg'et i den refleksive bevidsthed til at styre bevidstheden og den aktive handling $\mathrm{i}$ en bestemt retning og derfor kan det ofte være vanskeligt at differentiere mellem det intentionelle aspekt på henholdsvist et spontant og et refleksivt bevidsthedsniveau.

Bevidsthedsaspekterne er oplevelsens byggestene og det er således også dem der ligger til grund for den fænomenologiske beskrivelse når en person forsøger at beskrive hvad han eller hun har oplevet i en nærmere bestemt situation. 
Bevidsthedens subJeKtive status

Oplevelser manifesterer sig i det enkelte individs bevidsthed og er ikke direkte tilgængelige for andre. De indtryk, følelser og tanker som en person har, er i deres grundlæggende form subjektive. Fænomenologiens primære genstand er derfor kun direkte tilgængelig for den person som har oplevelsen. Den fænomenologiske metodes opgave bliver at overvinde eller at forholde sig til oplevelsens subjektivitet.

Fænomenologiens fokus på den subjektive oplevelse er ofte forbundet med solipsisme. Når verden og livet kun er tilgængelige gennem oplevelse, er den subjektive bevidsthed måske det eneste der eksisterer. Det er klart at når en oplevelse udelukkende manifesterer sig i den subjektive bevidsthed, er der principielt ingen basis for at forudsætte en materiel og social verden. På den anden side er det en $\mathrm{fx}$ nomenologisk kendsgerning at mennesker i almindelighed oplever at deres eksistens både finder sted og er afhængig af en omgivende virkelighed der eksisterer uafhængigt af deres egen bevidsthed.

Solipsisme er således en filosofisk og ikke en psykologisk problemstilling på anden måde end at det er psykologiens opgave at forklare hvorfor mennesket oplever sig som en del af en større virkelighed når det rent faktisk kun har sine egne oplevelser at forholde sig til.

Bevidsthedens subjektive status betyder at det fænomenologisk givne har privat karakter. På den anden side, i den udstrækning at to eller flere personer drager de samme erfaringer, betyder sådanne fælleserfaringer at de i en given situation oplever det samme og at disse oplevelser bliver intersubjektivt kommunikerbare. Når et barn oplever at det gør ondt at holde hånden over et brændende stearinlys lærer det ikke blot at ild brænder, men bliver også i stand til at dele en sådan erfaring med andre. I et metodisk perspektiv er spørgsmålet derfor ikke solipsisme eller ej, men hvorledes de problemer der er forbundet med at fastholde, iagttage og konceptualisere specifikke oplevelser overvindes og hvorledes de gøres forståelige for andre som ikke selv har haft præcis de samme oplevelser.

\section{INTROSPEKTION}

Den fænomenologiske metode har sit udgangspunkt i menneskets evne til at iagttage sin egen bevidsthed. Denne selviagttagelse kaldes almindeligvis introspektion. Indledningsvis skal det slås fast at introspektion i fænomenologisk perspektiv er en metode til at beskrive bevidsthedslivet. Det vil sige at alle bevidsthedens aspekter uanset om der er tale om sansede indtryk, emotioner eller andet, ligger inden for de fænomenologiske studiers interessefelt. I princippet er introspektion en indadskuen for at beskrive hvad der træder frem i bevidstheden, men visuelle sanseindtryk for eksempel er fænomenologisk lokaliseret i omgivelserne uden derved at blive udelukket fra introspektiv iagttagelse. Mange beskrivelser inden for den klassiske litteratur giver anledning til den opfattelse at introspektion udelukkende beskæftiger sig med indre manifestationer som for eksempel forestillingsbilleder og tanker i modsætning til perception af de ydre omgivelser, men dette er en uheldig begrænsning som ikke er i overensstemmelse med en fænomenologisk opfattelse.

Vender vi for et øjeblik tilbage til det indledende eksempel med publikum der introduceres til Lemmerz' kunstværk, kan vi forestille os hvorledes forestillinger og tanker spontant dukker op i deres bevidsthed. De bliver måske endog emotionelt stemt før de står over for 
24 billedet. Selv om de ikke er instrueret til at huske hvad der løber gennem deres bevidsthed, vil der altid være en spontan refleksiv opmærksomhed der fastholder sider af oplevelsen i erindringen.

I den eksperimentelle situation kan der vælges mellem to forskellige fremgangsmåder. Enten aktiv intentionel introspektion hvor forsøgspersonen instrueres til at forholde sig iagttagende til sin egen bevidsthed, eller en fremgangsmåde hvor forsøgspersonen indtager en naturlig indstilling med spontan vekselvirkning mellem oplevelse og refleksion. Bagefter anmodes den pågældende om at beskrive oplevelsen ud fra de indtryk som kan genkaldes i erindringen. Sidstnævnte fremgangsmåde kaldes retrospektiv introspektion eller blot retrospektion.

Der er flere problemer forbundet med den introspektive metode. En af de væsentligste er at det er uvant for de fleste mennesker at forholde sig intentionelt iagttagende til deres egen bevidsthedsstrøm. Den almindelige bevidsthed er kendetegnet ved en konstant vekselvirkning mellem spontan og refleksiv bevidsthed og derfor er der også en spontan opmærksomhed om hvad der foregår i livet og bevidstheden. Med andre ord, der foregår en naturlig introspektion i det daglige liv. Horace Bidwell English $(1921,404)$ beskriver det på følgende måde: "Introspection is a natural type of behavior. We all introspect frequently, just as we observe in other ways. For introspection is simply observing our own experience. When we say 'I feel warm,' we have introspected." Det er således ikke den introspektive selviagttagelse der er uvant, men det er uvant at foretage introspektionen intentionelt. Almindeligvis indgår introspektion som en kognitiv funktion i en aktivitet hvor det intentionelle er rettet mod en opgave der ligger uden for bevidst- heden. Når introspektion anvendes som metode i fænomenologiske studier opstår en ganske anden situation. Den refleksive bevidsthed rettes mod en spontan bevidsthedsstrøm, men når pågældende person primært er beskæftiget med at iagttage sin egen bevidsthed, ophører den bevidsthedsstrøm som er studiernes primære interesse. Ønsker man for eksempel at studere en kunstoplevelse forudsætter det naturligvis at personen oplever et kunstværk, men hvis pågældende får til opgave at iagttage sin egen kunstoplevelse, flyttes bevidsthedens fokus fra kunstværket til kunstoplevelsen som netop ophører når betragteren holder op med at betragte kunstværket. Forholdet mellem væren og introspektion bliver endnu tydeligere i følelsesladede situationer hvor for eksempel vrede får en helt anden karakter og måske endog helt ophører i det øjeblik den betragtes refleksivt.

Dette dilemma er det allerstørste problem ved den introspektive metode og gennem fænomenologiens historie er der gjort forskellige forsøg på at håndtere problemet konstruktivt. Brentano $(1874,40)$ skelner således mellem indre perception (innere Wahrnehmung) og indre observation (innere Beobactung) og påstår at det er gennem indre perception og ikke observation at man har lært hvad en tanke er, hvad en følelse af lyst er, en smerte, et ønske, et synspunkt og så videre. Hvis man observerer bevidstheden, ændrer man den bevidsthed man ønsker at observere. I stedet må man ifølge Brentano rette opmærksomheden mod et objekt eller hændelsesforløb mens man forsigtigt iagttager hvad der aktualiseres i bevidstheden. Det er kun mens opmærksomheden er rettet mod et objekt at man er i stand til lejlighedsvis eller i forbigående at percipere hvad det er der foregår i bevidstheden. Introspektion er i hans opfattelse et forsøg på indre 
observation af de mentale fænomener og en sådan observation lader sig netop ikke gennemføre uden at ændre den bevidsthed man ønsker at observere. I stedet for, må man ifølge Brentano (ibid., 30) lade opmærksomheden rette sig mod et objekt mens man i forbigående forsøger at percipere de processer som finder sted i og med at opmærksomheden er rettet mod dette andet objekt. Den grundlæggende metode i psykologisk videnskab er derfor ifølge Brentano (ibid., 43) indre perception, og ikke introspektion som han anser for at være umulig som metode til studie af psykiske fænomener.

I denne sammenhæng giver Brentanos synspunkt ikke anledning til at udskifte begrebet introspektion med begrebet indre perception. For det første anses problemet som et spørgsmål om at afklare hvad introspektion er eller kan være hvilket ikke er tilstrækkelig anledning til at introducere en ny metode og et nyt begreb. Når Brentano introducerer begrebet "indre perception" er det fordi han har travlt med at lægge afstand til den fremstormende psykofysiske psykologi med Wilhelm Wundt i spidsen. Wundt (1888) anvendte begrebet introspektion (innere Beobachtung) om indre observation af psykiske fænomener og derfor var det vigtigt for Brentano at præcisere sin egen metode. Dette forhold er ikke længere aktuelt. Desuden er Brentanos begreb indre perception ikke velvalgt fordi det giver indtryk af at det drejer sig om en sanselignende proces. At man så at sige med det "indre øje" anskuer det der er i bevidstheden. Men introspektion i betydningen indre perception er ikke kun en sanselignende proces, det er en refleksiv proces hvor den oprindelige spontane bevidsthed afspejles på en måde der svarer til denne bevidstheds fremtrædelsesform. Brentano har ikke gjort sig klart at emotioner for eksempel ikke primært lader sig iagttage gennem perception, men afspejles i deres oprindelige fremtrædelsesform og som sådan fastholdes i opmærksomheden.

Brentano (1982, 28-49) peger på en række forhold der fremmer introspektive studier. Det er således af betydning at introspektion finder sted under forhold der almindeligvis forbindes med selviagttagelse. Ophold i naturen, på kunstmuseum eller lignende steder er for eksempel af mange forbundet med længerevarig spontan introspektion, mens stressede situationer på arbejde og i trafikken bestemt ikke er befordrende. Det er ligeledes vigtigt at udelukke eller i al fald reducere forstyrrende momenter der ikke indgår i de pågældende studier. Desuden er det fremmende for introspektion at personen er vågen og frisk samt $i$ en passende emotionel tilstand. Introspektion skal således ikke forveksles med hypnagoge tilstande som til tider opstår umiddelbart før en person falder i søvn. Det kræver årvågenhed at fastholde og genkalde sig de bevidsthedsfænomener som skal iagttages. Derfor er det også vigtigt at introspektionisten, eller psykognosten som Brentano kalder vedkommende, er i en emotionel tilstand der befordrer en skarp opmærksomhed. Affekt, frygt, vrede og andre stærke sindstilstande forstyrrer og forhindrer til tider introspektive studier.

Brentano peger desuden på at det er vigtigt at introspektionisten ikke har modvilje eller fordomme over for de fænomener som studeres. Enhver form for forbehold eller afstandtagen vil ikke blot forstyrre den introspektive iagttagelse, men også være fatal for den fænomenologiske beskrivelse. Især er det vigtigt at være opmærksom på fordomme der er rodfæstet $\mathrm{i}$ vane. Brentano gør opmærksom på at holdningsmæssige og teoretiske indstillinger virker forstyrrende på introspektive iagttagel- 
26 ser og at det er vigtigt med en umiddelbar og neutral indstilling. På dette punkt synes hverken Brentano eller hans elev Edmund Husserl at være tilstrækkeligt opmærksomme på at bevidstheden som helhed og den refleksive del i særdeleshed er influeret af erfaringsbaserede kognitive faktorer og at tanken om en "ren skuen" er urealistisk. Udfordringen er derfor ikke at eliminere de kognitive aspekter hvilket er umuligt, men at skelne mellem den spontane bevidsthed og de forskellige udtryk for refleksiv virksomhed. Sidstnævnte er nemlig fremtrædelsesformer der ikke kan sidestilles med fænomenologisk iagttagelse og beskrivelse. Når Brentano advarer mod særlige holdningsmæssige og teoretiske indstillinger taler han sandsynligvis om en refleksiv indstilling som udelukker reelle introspektive iagttagelser.

Endelig inddrager Brentano tidsfaktoren som en forudsætning for frugtbare introspektive studier. Det er særdeles befordrende for selviagttagelse at den iagttagende person både har tid til at indtage den rette position og tid til at gennemføre og måske gentage de introspektive iagttagelser.

Angående tidsfaktoren tilføjer English (1921, 409) at oplevelser udset til introspektion ikke bør være for lange. Hans opfordring til ikke at overstige to sekunder synes dog at være ude af trit med almindelige psykologiske undersøgelser med mindre et oplevelsesforløb opdeles i flere fortløbende sekvenser.

Angående den introspektive metode peger English på et problem som allerede Descartes var opmærksom på, nemlig en tendens til ubevidst at skifte fra en opmærksomhed på oplevelsen til en opmærksomhed på ydre forhold. Problemet er reelt nok i den forstand at der er en stærk tendens under introspektion til at fokusere på det visuelle aspekt af oplevelsen, eller med andre ord, at fokusere på omverdenens fremtrædelsesform og dermed overse andre aspekter. At skelne mellem oplevelse som noget indre og en fysisk omverden som noget ydre er ikke i overensstemmelse med en fænomenologi hvor ethvert forhold til livet og verden aktualiseres i bevidstheden. Det er ganske enkelt ikke muligt at iagttage en bevidsthedsuafhængig omverden.

Direkte introspektive iagttagelser anvendes sjældent i fænomenologisk forskning i dag. Allerede tidligt i den akademiske psykologis historie var der intens diskussion om den introspektive metode blandt fremtrædende psykologer som Brentano, William James, Oswald Külpe, Edward Bradford Titchener, Wundt og andre. Trods meningsforskelle var der udbredt enighed om at introspektion var så krævende at den kun kunne gennemføres af trænede forsøgspersoner. Det forlyder blandt andet at en forsøgsperson i Wundts laboratorium skulle gennemføre over titusinde introspektive studier for at kunne deltage i et publicérbart forskningsprojekt (Boring 1953, 172). Mens gestaltpsykologerne i en vis udstrækning fortsatte med trænede forsøgspersoner i deres forskning gled fremgangsmåden med direkte introspektive studier i baggrunden og i dag nævnes den introspektive metode sjældent $\mathrm{i}$ forbindelse med fænomenologisk forskningsmetodologi selv om James' (1890, I: 185) udsagn om at introspektive observationer er det eneste vi har at bygge på, er lige så sandfærdigt i dag som dengang det blev udtalt.

\section{Retrospektion}

Fænomenologisk forskning bygger i dag fortrinsvis på de refleksive selviagttagelser som den enkelte spontant udfører i såvel dagligdagens situationer som under eksperimentelt ar- 
rangerede forhold. Sådanne iagttagelser er i princippet en form for introspektion, men den videnskabelige registrering af de pågældende oplevelser finder almindeligvis sted på et tidspunkt der ligger efter den oplevelse der undersøges. Forsøgspersonen må derfor genkalde sig den oprindelige oplevelse. I undersøgelsen på Esbjerg Kunstmuseum, lytter deltagerne til en af de fire introduktioner og ser det udstillede kunstværk uden i forvejen at blive instrueret om selviagttagelse. Det er først i det efterfølgende interview at de bliver bedt om at beskrive de oplevelser de havde under introduktionen og den efterfølgende konfrontation med kunstværket. Den interviewede må således genkalde sig de oplevelser som vedkommende havde i den eksperimentelle situation, det vil sige, at de aspekter som den refleksive opmærksomhed har hæftet sig ved under selve oplevelsen, forsøges genaktualiseret. I bedste fald genopleves den oprindelige situation med udgangspunkt i de hukommelsesspor som kan aktiveres i den refleksive hukommelse. Det vil sige at enhver genaktualisering af en tidligere oplevelse for det første er afhængig af den individuelle kognitive opfattelse af den oprindelige situation og for det andet, vil blive præget af de nye fantasier som enhver erindring kan give anledning til.

Mens den introspektive metode er behæftet med en række vanskeligheder med at opretholde den oprindelige oplevelse under den samtidige selviagttagelse, er den retrospektive metode vanskeliggjort af de forhold der hersker omkring genkaldet af en tidligere oplevelse i dens oprindelige form. Brentano (1874, 35) som kalder den retrospektive metode for "observation i erindringen", påpeger at metoden ikke er ækvivalent med introspektion, men at man med den retrospektive metode $\mathrm{i}$ modsætning til den introspektive let bliver offer for bedrag fordi en række forhold ved 27 hukommelsen ændrer på den oprindelige iagttagelse. Der skal i denne sammenhæng ikke gøres nærmere rede for hukommelsesfunktionen og de forhold der kan påvirke erindringen, men det er klart at den refleksive hukommelse er en kognitiv funktion og derfor ikke reproducerer, men udelukkende genfremkalder træk ved den oprindelige oplevelse. Det er med andre ord et genskin af oplevelsen som danner grundlag for retrospektion, også selv om den foretages umiddelbart efter den oplevelse som er genstand for undersøgelse. Derfor kan man heller ikke forvente at den retrospektive introspektion kan bidrage kreativt til beskrivelsen af et bestemt fænomen. Erindringen er determineret af det kognitive beredskab. Det vil sige at en erindring er formet af det bestående kognitive beredskab og giver derfor ikke grundlag for en kreativ overskridelse af det bestående. Den direkte introspektion derimod fokuserer på bevidsthedens egen natur som ikke udelukkende er kognitiv. Betingelser som er en forudsætning for skabende virksomhed der kan give grundlag for ny indsigt $\mathrm{i}$ den menneskelige bevidsthed og eksistens.

Selv om retrospektive studier næppe giver grundlag for ny indsigt, giver de alligevel grundlag for en mere systematisk beskrivelse af enkeltfænomener. I fænomenologiske undersøgelser er fremgangsmåden at isolere specifikke oplevelser for at koncentrere undersøgelsen på afgrænsede fænomener som det indledende eksempel om introduktion til billedkunst illustrerer. Dette giver ikke blot grundlag for en mere grundig og systematisk undersøgelse af disse fænomener, men også mulighed for at indsamle data fra flere personer således at det samlede datamateriale giver grundlag for en nuanceret beskrivelse af det pågældende fænomen. Det er muligt at sådanne 
28 beskrivelser af isolerede fænomener baseret på retrospektiv introspektion ikke bidrager med kvalitativt nye iagttagelser, men de vil oftest give et samlet billede af det pågældende fænomen som man tidligere ikke har haft noget overblik over. Sådanne overblik kan i mange tilfælde være en forudsætning for et konstruktivt handlingsprogram. Med andre ord, uden indsigt og overblik over et fænomen som for eksempel den æstetiske oplevelse vil det være halsløs gerning at udvikle et kunstformidlingsprogram der søger at fremme publikums personlige engagement i billedkunst.

Retrospektive studier hvor en oplevelse genkaldt i erindringen danner grundlag for den fænomenologiske beretning, er ikke blot den hyppigst anvendte metode i fænomenologisk forskning, det er tillige en fremgangsmåde som svarer til en situation i dagligdagen hvor der fortælles om en særlig begivenhed. Den retrospektive metode er til forskel fra den introspektive en fremgangsmåde som svarer til hvad mennesker gør i almindelighed når de beretter om en oplevelse de har haft. Den behøver derfor ingen særlig instruktion, men kan gennemføres som om det er en ganske almindelig samtale om noget de har oplevet. Den fænomenologiske samtale eller interview kræver derimod stor opmærksomhed fra forskerens side med henblik på at fokusere interviewpersonens opmærksomhed på det fænomen som undersøgelsen drejer sig om.

\section{FæNOMENOLOGISK INTERVIEW}

Fænomenologiens metodologiske problem er oplevelsens subjektive status. Der er ingen direkte adgang til et andet menneskes oplevelser og derfor må den fænomenologiske forskning gå forskellige omveje for at indhente de data en fænomenologisk beskrivelse bygges på. I princippet kan ethvert menneskeligt udtryk lægges til grund for en fænomenologisk beskrivelse, men i denne sammenhæng vil kun det fænomenologiske interview som er en af de mest sofistikerede metoder til belysning af det menneskelige bevidsthedsliv, blive omtalt.

Formålet med det fænomenologiske interview er at indhente oplysninger der gør det muligt at beskrive et afgrænset fænomen så nøje og nuanceret som muligt. Derfor karakteriseres det fænomenologiske interview som en explorativ og kvalitativ metode, det vil sige, at det anvendes til at "gå på opdagelse i" eller at undersøge forhold som endnu ikke er tilstrækkeligt belyst. Metoden er kvalitativ fordi den fokuserer på kvaliteten eller karakteren af de forhold som undersøges til forskel fra kvantitativ forskning hvor allerede kendte forhold registreres med henblik på at bestemme mønstre og tendenser på baggrund af den hyppighed hvormed de forekommer.

Det fænomenologiske interview er en dialog mellem en person der har haft en oplevelse og en forsker som ønsker et indblik i denne oplevelse med henblik på at fremstille en nuanceret beskrivelse af det pågældende fænomen. De forhold som konstituerer interviewet som forskningsmetode, er så komplekse at det i denne sammenhæng ikke er muligt at give et generelt overblik. Kun nogle få centrale forhold omkring informanten eller interviewpersonen, forskeren/intervieweren og den anvendte interviewteknik skal berøres.

Almindeligvis udvælges interviewpersonerne ikke efter særlige kriterier bortset fra at det er en forudsætning at vedkommende har haft en oplevelse i sin daglige tilværelse eller under arrangerede eksperimentelle forhold som kan bidrage til beskrivelse af undersøgelsens fænomen. Formålet med fænomenologiske undersøgelser er at beskrive særlige bevidsthedsfæ- 
nomener så nøje og nuanceret som muligt. Formålet er ikke at beskrive karakteristiske træk ved de personer som har haft den pågældende oplevelse. Der er derfor heller ingen grund til at foretage en udvælgelse af interviewpersoner efter særlige kriterier.

Antallet af interviewpersoner i en undersøgelse afhænger af undersøgelsens ambitionsniveau. Jo flere interviewpersoner, jo flere beskrivelser af undersøgelsens fænomen, og dermed også grundlag for en mere nuanceret beskrivelse. I princippet er en fænomenologisk beskrivelse et uafslutteligt projekt fordi den spontane oplevelse fremtræder på en måde der aldrig lader sig fuldstændig bestemme. Derfor vil det altid være en spørgsmål hvornår den fænomenologiske beskrivelse er tilstrækkelig. I mange tilfælde vil det være projektets praktiske formål der blive afgørende for hvornår en fænomenologisk beskrivelse kan anses som værende tilstrækkelig. I det øjeblik en fænomenologisk beskrivelse overskrider hidtidig indsigt og bringer den psykologiske forståelse på et mere nuanceret niveau end hidtil, kan man sige at den fænomenologiske forskning har nået et væsentligt resultat. Det er således ikke antallet af informanter der er afgørende, men det kvalitative udbytte af de enkelte interview.

Det fænomenologiske interview engagerer interviewpersonen $\mathrm{i}$ en psykologiske proces med at omsætte en oplevelse til en sproglig beskrivelse. Der er således tale om at konvertere et bevidsthedsfænomen til et medium der er kvalitativt forskelligt fra bevidsthedens. Selv om alle mennesker, oftest mange gange dagligt, foretager sådanne "konverteringer" af deres oplevelser, er det naturligvis ikke alle der gør det med samme præcision og nuancerigdom. Adrian van Kaan $(1966,328)$ opregner seks forhold som han anser som forudsætning for kvalitativ fænomenologisk beskrivelse. For det første må informanten have forholdsvis let ved at udtrykke sig i det sprog som anvendes. Han eller hun må have færdighed til at sanse og udtrykke egne følelser uden at føle sig hæmmet og uden at føle skam. For det tredje må informanten have færdighed til at sanse og udtrykke de kropslige oplevelser som optræder i forbindelse med følelser. Det skal tilføjes at informanten i det hele taget må være sensitiv over for alle oplevelsens aspekter. Mange mennesker er uvante med at forholde sig til bevidsthedens fremtrædelsesformer og udtrykker sig fortrinsvis gennem synspunkter og holdninger.

Kaan fremsætter desuden krav om at oplevelsen der beskrives, bør være relativ ny, og at informanten bør have en spontan interesse $i$ den oplevelse som han eller hun beskriver. Endelig bør situationen hvor beskrivelsen finder sted være afslappet og foregå uden tidspres.

Kaans kriterier gør det klart at både psykologiske færdigheder hos informanten og formelle forhold $\mathrm{i}$ interviewsituationen har betydning for den fænomenologiske beretning, men også den anvendte interviewteknik er en afgørende faktor. Almindeligvis anvendes fokuserende, fleksibel og åben spørgeteknik i det fænomenologiske interview. Det vil sige at spørgsmålene ikke er formuleret i forvejen, men at der er truffet forberedelser til at anskue det pågældende fænomen fra forskellige synsvinkler således at opfordringer til at beskrive og udspørgning tilpasses det enkelte individ. Det er interviewerens opgave at informantens opmærksomhed igen og igen rettes mod undersøgelsens fænomen hvilket kun kan lade sig gøre når forskeren i forvejen har tilegnet sig et bredt kendskab til det pågældende fænomen. Det kan diskuteres om det er en for- 
30 udsætning at forskeren har personligt kendskab til undersøgelsens fænomen. William James er for eksempel berømmet for sin beskrivelse af den religiøse oplevelse på trods af at han (1902, 370) ifølge eget udsagn ikke selv havde haft en sådan oplevelse. På den anden side kan der næppe herske tvivl om at personlig erfaring giver nogle oplevelsesmæssige forudsætninger som tilegnet viden ikke gør og som derfor giver grundlag for en mere nuanceret dialog.

Det fænomenologiske interview er ikke kun fokuserende ved at holde undersøgelsens fænomen i centrum selv om der skiftes perspektiv, men også ved at fokusere på informantens engagement. Det er fremmende for den fænomenologiske beretning at informanten ikke blot er interesseret i de forhold sagen drejer sig om, men at samtalen tager udgangspunkt i forhold som informanten er blevet emotionelt påvirket af. Det emotionelle engagement ansporer i mange tilfælde til explorativ selviagttagelse.

At den fænomenologiske spørgeteknik er fleksibel, betyder at den indrettes i forhold til informantens personlige karakter og stemning. Dialogen har til formål at skabe de rette betingelser for informantens selvrefleksion og konceptualisering og sådanne betingelser varierer fra person til person og måske endog fra tid til tid. Mens én person behøver tid og fordybelse, fremmes koncentration og indlevelse gennem udfordring og dialog hos en anden. De sproglige formuleringer og referencer der anvendes i udspørgningen, bør på tilsvarende måde varieres fra person til person. Tilsyneladende uvæsentlige detaljer i den sproglige formulering af spørgsmål kan få afgørende betydning for den fænomenologiske beretning. Opfordres informanten til for eksempel at beskrive hvad han eller hun har "set" i stedet for "oplevet" vil beretninger i mange tilfælde være begrænset til synsindtryk. Mens begrebet "opleve" for de fleste også inkluderer følelsesmæssige reaktioner og andre aspekter.

At det fænomenologiske interview er åbent betyder at hverken informant eller forsker kender det endelige resultat af dialogen. I princippet kan interviewet fortsætte i det uendelige fordi ethvert fænomen kan betragtes fra utallige synsvinkler og beskrivelsen kan varieres og revideres uden at nå et absolut resultat. Samtalen må derfor afsluttes når hverken informant eller forsker formår at bibringe den fænomenologiske beretning yderligere nuancer.

Det er en udbredt opfattelse at interviewet er en metode til at indhente viden. Steinar Kvale $(1997,15)$ beskriver således interviewet som "en udveksling af synspunkter mellem to personer der taler sammen om et tema af fælles interesse." Det er "et produktionssted for viden," skriver han. Det fænomenologiske forskningsinterview er ikke kun et "inter-view" en udveksling af synspunkter - men først og fremmest en ind-sigt i informantens oplevelse - den oplevelse som genaktualiseres i bevidstheden som udgangspunkt for beskrivelse.

Det fænomenologiske interview er en dialog hvor forskeren gennem empatisk indlevelse forsøger at danne sig et indtryk af den oplevelse som der berettes om. Det er således ikke blot et spørgsmål om at forstå den sproglige beretning, men om at lade beretningen stimulere den spontane bevidsthed i en bestræbelse på at opleve det "samme" som informanten. Gennem samtale opbygges i forskerens bevidsthed et indtryk som i den udstrækning det er muligt, svarer til informantens oplevelse og det er denne oplevelse som danner grundlag for den fænomenologiske beskrivelse. Dette kan umiddelbart opfattes som en omstændelig pro- 
cedure, men det er i princippet det samme der sker under almindelig samtale hvor en person beskriver en oplevelse vedkommende har haft. Det er ikke ordene og ikke ordenes betydning, men de glimt af visuelle billeder, stemninger, engagement med mere som aktualiseres i lytterens bevidsthed der er det egentlige grundlag for opfattelsen af den anden persons oplevelsesverden. En sådan empatisk indlevelse er ikke nødvendigvis begrænset af lytterens egen erfaring. På det kognitive niveau er oplevelsen naturligvis begrænset af lytterens beredskab til at forstå hvad fortælleren siger, men på det oplevelsesmæssige niveau har lytteren en forestillingskapacitet som rækker langt ud over erfaringen. Dette er for eksempel tydeligt i forbindelse med læsning af skønlitterære værker hvor en fiktiv verden udfolder sig i læserens bevidsthed uden at man kan tale om at denne fiktive verden refererer direkte til noget læseren kender i forvejen. På tilsvarende måde må forskeren gennem det fænomenologiske interview skabe betingelser for sin egen oplevelse af hvad informanten oplever eller har oplevet.

Empatisk oplevelse forudsætter en særlig mental indstilling som ikke blot betyder at en følelsesmæssig kvalitet opleves som tilhørende et andet menneske (eller ting), sådan som Theodor Lipps (1903/06, 2:1) definerer empati. Det er en indstilling på at opleve en andens oplevelse så totalt som overhovedet muligt.

Fordelen ved den empatiske metode er at forskeren kan fastholde oplevelsen som fokus for beskrivelse. Når en interviewperson for eksempel siger: "Det var en fantastisk oplevelse," er det naturligvis forskerens opgave at få informanten til at fokusere på oplevelsens fremtrædelsesform og beskrive den mere direkte for eksempel ved at forskeren ligesom terapeuten i klient-centreret terapi gentager

hvad interviewpersonen lige har sagt, for at fastholde opmærksomheden på fænomenet og for at få det yderligere beskrevet. Samtidig er det forskerens opgave gennem empati at gøre sig en forestilling om hvad en "fantastisk oplevelse" er for den interviewede og danne sig et helhedsindtryk af det fænomen som det er projektets formål at beskrive.

Empatisk indlevelse er noget der hører med i enhver dialog og er ikke noget specielt for den fænomenologiske dialog. Det er blot vigtigt i denne sammenhæng at gøre opmærksom på at den sproglige beretning ikke i sig selv er interessant. Det er det indtryk den aktualiserer i lytterens eller læserens bevidsthed der er interessant, fordi det er det der i sidste instans lægges til grund for ny fænomenologisk indsigt.

\section{FÆNOMENOLOGISK BESKRIVELSE}

Tidspunktet er inde til at danne sig et overblik over den fænomenologiske metode. Al fænomenologisk forskning fokuserer på den direkte og umiddelbare oplevelse. Forud for den fænomenologiske dataindsamling defineres og afgrænses undersøgelsens fænomen. Det kan for eksempel være den oplevelse som er forbundet med at blive introduceret til et kunstværk på en særlig måde sådan som det er tilfældet i den undersøgelse som indleder denne artikel. I nævnte tilfælde er oplevelsen fremkaldt under eksperimentelle forhold. I andre tilfælde kan der være tale om oplevelser som spontant opstår i det daglige liv. Praktiske forhold kan være afgørende for om de fænomenologiske data indsamles gennem introspektion eller retrospektion og om de konceptualiseres i mundtlig eller skriftlig form eller eventuelt gives udtryk på anden måde. Disse fæ- 
32 nomenologiske beretninger danner grundlag for forskerens empatiske opfattelse af informantens oplevelse og gennem en bearbejdning som der redegøres for i det følgende, udformes den endelige beskrivelse af undersøgelsens fænomen.

Den fænomenologiske beskrivelse af et fænomen er således forskerens beskrivelse. Den er ganske vist baseret på de beretninger som undersøgelsen bygger på og ofte vil den fænomenologiske beskrivelse indeholde direkte citater af de primære beretninger, men den endelige beskrivelse er afhængig af den måde hvorpå forskeren opfatter og forholder sig til de fænomenologiske data.

I spørgsmålet om fænomenologisk beskrivelse kan man ikke komme uden om den tyske filosof Edmund Husserl. Om nogen er Husserl forbundet med begrebet fænomenologi og den fænomenologiske metode. Det er i denne sammenhæng vigtigt at gøre sig klart at Husserls projekt var filosofisk og ikke psykologisk metodisk. For Husserl er det fænomenologiens opgave at undersøge de filosofiske spørgsmål som vedrører virkelighedens beskaffenhed, og han har ingen særlig interesse i beskrivelsen af det subjektive bevidsthedsliv. Alligevel er der mange psykologer (Giorgi 1985, 1994; Moustakas 1994; Spinelli 1989) der er inspireret af Husserls tanker og som har forsøgt at applicere hans principper på psykologisk undersøgelsesmetodik.

Husserls (1913, \$ 24) udgangspunkt "princippernes princip" som han kalder det er at ren betragtning er kilde til al erkendelse. En forudsætning for at vende sig mod det fænomenologisk givne er at man suspenderer den såkaldt naturlige indstilling til virkeligheden for at fokusere på tingene selv. Epoché (gr. holden tilbage, standsning) som er betegnelsen for denne indstilling, betyder at alle antagelser om verden og især antagelsen om verdens bevidsthedsuafhængige eksistens suspenderes. Dette betyder ikke at Husserl betvivler at verden eksisterer i sig selv, men blot at det er absurd at tale om den uden at gøre sig klart at det er gennem vor bevidsthed at vi kender verden. Når der tales om noget i verden, er det altid noget der er sanset, forestillet, følt eller tænkt; det er aldrig noget som er uafhængigt af den menneskelige bevidsthed. Maurice MerleauPonty (1962, viii) siger det på følgende måde: "Hele mit kendskab til verden, selv min videnskabelige viden, stammer fra min egen personlige tilgang, eller fra oplevelser af verden uden hvilke videnskabens symboler ville være meningsløse."

Epoché er en fokusering på fænomenerne (tingene selv) og tjener derfor også det formål at gøre det muligt at undersøge verden som den er uafhængig af enhver antagelse og teori. Samtidig er epoché forudsætning for at kunne studere den transcendentale subjektivitet som er grundlaget for ethvert fænomens fremtræden. Det skal tilføjes at der i denne forbindelse også tales om den transcendentale reduktion.

Den engelske psykologi Ernesto Spinelli (1989, 17) har appliceret Husserls princip om epoché til den fænomenologiske metode som et princip om at suspendere antagelser, fordomme og forventninger man kan have til et fænomen. Epoché er ifølge Spinelli en tilskyndelse til at være åben for den umiddelbare oplevelse. Som eksempel nævner han den situation hvor man i forvejen har hørt noget om en person og vanskeligt kan opleve vedkommende uden denne viden. Spinelli omtaler epoché som et generelt princip i den fænomenologiske metode, og det fremgår ikke om det er fra subjektets perspektiv eller forskerens perspektiv. Som forsker kan man naturligvis 
opfordre den enkelte til at forholde sig fordomsfrit til sine oplevelser, men oftest vil instruktioner om at forholde sig på en speciel måde komplicere betragterens opgave. Ofte vil en person ikke have et refleksivt forhold til sine egne antagelser og derfor heller ikke være i stand til at suspendere sine egne antagelser. Det er derfor forskerens opgave gennem sine spørgsmål at rette betragterens opmærksomhed mod fænomenets fremtrædelsesform og lade beskrivelse frem for fortolkning komme til udtryk.

Det kan i mange tilfælde være vanskeligt at skelne mellem beskrivelse og fortolkning. Tag blot udsagn som "billedet er rødt" og "billedet er godt". Det første er en beskrivelse af en visuel kvalitet ved det pågældende billede, mens det andet er en vurdering eller dom over billedets kunstneriske kvalitet. Ifølge princippet epoché er det første udsagn en ren beskrivelse af det oplevede fænomen, mens det andet er udtryk for vurdering der siger mere om betragteren end om billedets fænomenologiske fremtrædelsesform. Men så enkelt er det ikke. Udsagnet "billedet er godt" kan både være resultat af forskellige overvejelser og dermed et udtryk for den refleksive forholden sig til fænomenet, men det kan også være udtryk for en umiddelbar oplevelse og dermed en ren fænomenologisk beskrivelse.

En oplevelse har altid kognitive aspekter fordi det alment kognitive beredskab indgår i enhver oplevelse. Man oplevelser for eksempel ikke blot det der svarer til et sanseindtryk, men et sanseindtryk der er identificeret som noget bestemt, for eksempel en rose. Det er klart at uden viden om en blomst der kaldes rose, vil ingen umiddelbart opleve at en blomst er en rose. Det forudsætter en viden som indgår i det almene beredskab for den spontane bevidsthedsstrøm. Uden et sådant kognitivt beredskab vil mennesket sandsynligvis blot opleve en "stor blomstrende, summende forvirring" som James ifølge Allport (1961, 111) talte om i forbindelse med den nyfødtes første sanseindtryk. Gennem livsløbet opbygges en stor fond af viden som indgår i det kognitive beredskab i mødet med livets vilkår. At noget er "godt" og andet "dårligt" er vurderinger der på tilsvarende måde kan indgå i det almindelige beredskab og derfor være udtryk for en umiddelbar oplevelse. Vi taler ofte om en intuitiv fornemmelse for hvad der er godt og hvad der er skidt, fordi det oprindelige grundlag for vurderingen ikke nødvendigvis bliver aktualiseret sammen med vurderingen.

Når man som forsker lytter til andres fænomenologiske beretninger er det derfor nødvendigt at skabe forudsætninger for at skelne mellem fænomenologisk og refleksiv beskrivelse. Det kan sjældent afgøres på den sproglige formulering alene fordi en og samme formulering kan være udtryk for både det ene og det andet. Forskeren må skabe sig klarhed over hvilken intentionalitet der ligger bag beskrivelsen. Søger vedkommende at beskrive sin oplevelse eller er vedkommende i færd med at promovere et synspunkt?

Den fænomenologiske reduktion er et væsentligt skridt frem mod en beskrivelse af et bestemt fænomen i dets konkrete fremtrædelsesform i den subjektive bevidsthed. Og selv om Husserls plan om at komme tilbage til "tingene selv" er uigennemførlig fordi de personlige erfaringer er med til at konstituere den spontane oplevelse, er det alligevel et forsøg på at tage udgangspunkt i fænomenerne sådan som de fremtræder umiddelbart.

Spinelli (1989, 17-19) udleder to andre principper af Husserls filosofi, nemlig princippet om beskrivelse og princippet om horisontalisering. Begge principper ligger i direkte for- 
34 længelse af det første princip om epoché. I den fænomenologiske beskrivelse er det hensigten at komme så tæt på fænomenernes fremtrædelsesform som muligt, ikke blot ved at sætte parentes om de opfattelser der ligger forud, men også ved at undgå enhver fortolkning af de fænomener der beskrives. Med andre ord, beskrivelsesprincippet er en opfordring til at beskrive og ikke at tillægge betydning eller at forklare. Princippet om horisontalisering eller ligestillelse er at sætte de forskellige dele af beskrivelser på lige fod. Intet skal tillægges mere betydning end noget andet. Enhver evaluering hvor noget fremhæves på bekostning af noget andet er naturligvis et udtryk for stillingtagen der går ud over selve iagttagelsen og dermed ikke i overensstemmelse med de fænomenologiske beskrivelsesprincipper. På den anden side skal det ikke overses at den fænomenologiske beskrivelse inden for psykologisk forskning ofte har et eksistentielt perspektiv. Det vil sige at man gennem den fænomenologiske beskrivelse søger at definere de kvaliteter der karakteriserer menneskelig eksistens. I sådan forskning er det netop nødvendigt at være opmærksom på hvor den individuelle eksistens kommer mest intenst og fyldigt til udtryk.

Det ligger også i Husserls fænomenologi at ikke alle aspekter $\mathrm{i}$ et fænomens fremtrædelsesform er lige grundlæggende for fænomenets beskrivelse. Han $(1962, \$ 9)$ foreslår derfor en eidetisk variation hvor den umiddelbare oplevelse varieres i fantasien med henblik på at identificere væsentlige træk ved fænomenet. Når en oplevelse varieres i fantasien, eventuelt ved at inddrage flere beretninger om det samme fænomen, bliver det muligt at skelne mellem de træk ved fænomenet der beskriver fænomenet og de træk som tilfældigt hører med i det konkrete tilfælde. Psykologer som Giorgi (1994) og Moustakis (1994) har appliceret
Husserls ide om eidetisk variation til psykologisk forskning. De taler begge om "imaginative variation" som metode til at afdække fænomenets betydning (meaning). Giorgi (1994, 214) taler om "search for essence" og skriver: "The term essence is intelligible but it means nothing other than the search for an invariance that will render a host of variables more intelligible in the realm of meaning." Moustakas $(1994,99)$ skriver: "Systematic varying of the possible structural meaning that underlie the textural meanings." Både Giorgi og Moustakas giver udtryk for en særlig fænomenologisk opfattelse hvor kognitive aspekter opprioriteres på bekostning af emotionelle, intentionelle og sansede aspekter. I en fænomenologisk forskning hvor fænomenernes fremtræden i bevidstheden er det centrale, må den eidetiske variation gælde alle bevidsthedsaspekter i en bestræbelse på at beskrive fænomenet så nøje og nuanceret som muligt. Giorgis og Moustakas' opfattelse kan næppe være inspireret af Husserl som netop taler om en "eidetisk" variation og derved refererer til oplevelsens "billedlige" fremtrædelsesform og ikke en egentlig kognitiv opfattelse i form af fænomenets underliggende betydning. Husserls formulering kan i lighed med Giorgis og Moustakas' opfattelse, give anledning til en særlig fænomenologisk opfattelse hvor det visuelt sansede aspekt opprioriteres, men det har næppe været hans hensigt. I fænomenologisk psykologisk forskning hvor fænomenernes fremtræden i bevidstheden er forskningens udgangspunkt, må den eidetiske variation gælde alle bevidsthedsaspekter i en bestræbelse på at beskrive fænomenet så nøje og varieret som muligt. 


\section{EXPLORATIV FORSKNING}

Forskning i almindelighed er optaget af datamaterialets sandfærdighed og iagttagelsernes generaliserbarhed. Fænomenologisk psykologi deler ikke disse forskningsidealer. For det første hersker der ikke usikkerhed om de fænomenologiske iagttagelsers sandfærdighed. I princippet er de altid sande. Når en person beskriver et fænomen, kan beskrivelsen være mere eller mindre præcis og detaljeret, men den kan aldrig være usand med mindre personen forsøger at manipulere med resultaterne. Forholdet om fænomenologiske iagttagelsers og beskrivelsers sandfærdighed er naturligvis mere nuanceret. Vender vi tilbage til forholdet mellem spontan bevidsthed - som almindeligvis er fokus for fænomenologiske forskning - og refleksiv bevidsthed, er situationen den at fænomenernes fremtrædelsesformer er uudgrundelige. Ingen kan give en endelig og absolut beskrivelse eller gengivelse af et fænomens fremtrædelsesform i den spontane bevidsthed. Ovenstående fremstilling af den fænomenologiske metode har tillige givet et billede af de vanskeligheder der er forbundet med fænomenologisk iagttagelse og beskrivelse. Derfor er enhver fænomenologisk beskrivelse en tilnærmelse. At nå frem til en endelig og absolut beskrivelse af et fænomen er ganske enkelt ikke muligt. Den fænomenologiske forskning er en uendelig proces i en bestræbelse på at beskrive menneskets eksistens så nøjagtigt og detaljeret som muligt. Det er en bestræbelse som er styret af en specifik intentionalitet, hvilket vil sige at ethvert forskningsprojekt er begrænset af sit eget perspektiv. Idet dette perspektiv kan ændres uendeligt, er den fænomenologiske forskning et projekt uden afslutning. Dertil kommer at menneskets eksistentielle vilkår ændres som tiden går og der- med ændres også den menneskelige eksistens hvilket igen udfordrer til nye forskningsopgaver.

Spørgsmålet om de fænomenologiske iagttagelsers generaliserbarhed er kompliceret og indeholder blandt andet problematikken om intersubjektivitet. I denne sammenhæng begrænses spørgsmålet derfor til nogle få generelle overvejelser.

Som sagt er fænomenologiske data altid sandfærdige. Det vil sige at når to eller flere personer beskriver deres oplevelse i forbindelse med "samme" situation er den ene persons beskrivelse lige så rigtig eller sandfærdig som den andens. Vi kan vurdere om en beskrivelse er mere fokuseret på fænomenet, mere detaljeret og mere velformuleret; men den er ikke mere sand end enhver anden beskrivelse. Den fænomenologiske forskningsopgave er af samme grund explorerende, det vil sige at den søger at afdække det fænomen der fokuseres på, så grundigt som muligt. Når der inddrages flere personer $i$ en undersøgelse, er det med henblik på at få et så nuanceret billede af det pågældende forhold som muligt. Alle beretninger er lige-berettigede fænomenologiske data og først i den følgende teoretiske behandling foretages en vurdering af de indsamlede datas eksistentielle betydning.

\section{FÆNOMENOLOGI OG MUSEOLOGI}

Det centrale spørgsmål er hvordan fænomenologisk forskning kan bidrage til arbejdet på et museum. Indledningsvis er det værd at gøre sig klart at et museum, uanset hvilken kategori, råder over værdifulde samlinger som ofte er både enestående og betydningsfulde udtryk for samfundets kultur og historie. Enhver som arbejder på et museum kender fra personlig erfaring hvor menneskeligt tilfredsstillende det 
36 kan være at beskæftige sig med disse ting. Ofte undrer de sig over at ikke alle anerkender den rigdom som museerne er i besiddelse af. Der er mennesker som aldrig sætter deres ben på et museum og udspurgt vil de sikkert mene at museer er en unødvendig luksus.

Museumsvirksomhed bygger primært på fagspecifik viden. Der indsamles, registreres, bevares, forskes og formidles ud fra den faglige indsigt som er relevant i forhold til museets samlinger. Publikum derimod er som en ukendt by i Rusland. Der udføres ganske vist publikumsundersøgelser som fortæller noget om publikums adfærd i forhold til museerne. Hvor ofte de går på museum, hvad de foretrækker og så videre. Men vi ved meget lidt om hvilken psykologisk betydning museets samlinger kan have på den enkelte person, hvorledes de opdager museernes psykologiske værdi og hvorledes man befordrer formidlingen af samlingernes værdi i mødet med publikum.

Det er her den fænomenologiske forskning kommer ind i forhold til museets virksomhed. Ved at undersøge menneskets forhold til specifikke kunst-, kultur- og naturgenstande kan vi få et indblik i hvilken psykologisk betydning de kan have. Vi kan få et indblik i hvorfor nogle få mennesker er dybt fascineret af noget som andre betragter ligegyldigt. Gennem fænomenologisk forskning bliver museerne i stand til at forberede mødet mellem samlinger og publikum på en måde der opfattes relevant for den enkelte.

\section{RefERENCER}

Allport, G. (1961). Pattern and growth in personality. London: Holt, Rinehart and Winston. Originaludgave 1937.

Augustin (1991). Augustins bekendelser. København:
Sankt Angars Forlag. Originaludgave på latin c. 400.

Boring, E. G. (1953). A history of introspection. Psychological Bulletin 50: 169-189.

Brentano, F. (1874). Psychologie vom empirischen Standpunkt. Hamburg: Felix Meiner Verlag, 1924.

Brentano, F. (1995). Descriptive psychology. Translated by Benito Müller. London: Routledge. Originaludgave på tysk 1982 (lectures 1887-1891).

English, H. B. (1921). In aid of introspection. American Journal of Psychology 32: 404-414.

Funch, B. S. (2003). Introducing people to art: A study on the influence of art introductions. Under udgivelse.

Freud, S. (1965). Forelasninger til indforing i psykoanalysen. Oversat af Mogens Boisen. København: Hans Reitzels Forlag. Originaludgave på tysk 1916-1917

Giorgi, A. (1985). Sketch of a psychological phenomenological method. In Phenomenological and psychological research, edited by Amedeo Giorgi, 8-22. Pittsburgh, PA: Duquesne University Press.

Giorgi, A. (1994). A phenomenological perspective in certain qualitative research methods. Journal of Phenomenological Psychology 25: 190-220.

Husserl, E. (1913). Ideen zu einer reinen Phänomenologie und phänomenologischen Philosophie. Haag: Martinus Nijhoff, 1952.

Husserl, E. (1962). Phänomenologische Psychologie. Vorlesungen Sommersemester 1925. Haag: Martinus Nijhoff.

James, W. (1890). The principles of psychology. 2 vols. New York: Dover Publications, 1950.

James, W. (1892). Psychology. London: MacMillan, 1904.

James, W. (1902). The varieties of religious experience. New York: Modern Library.

Kaam, Adrian van (1969). Existential foundations of psychology. Garden City, NY: Image Books. 
Kvale, S. (1997). InterView: En introduktion til det kvalitative forskningsinterview. Oversat af Bjørn Nake. København: Hans Reitzels Forlag. Originaludgave på engelsk 1994.

Lipps. T. (1902/06). Ästhetik: Psychologie des Schönen und der Kunst. 2 vols. Hamburg: Leopold Voss.

Merleau-Ponty, M. (1962). Phenomenology of perception. Translated by Colin Smith. London: Routledge and Kegan Paul. Fransk originaludgave 1945.

Moustakas, C. (1994). Phenomenological research methods. Thousands Oaks: Sage Publications.

Spinelli, E. (1989). The interpreted world: An introduction to phenomenological psychology. London: Sage Publications.

Wundt, W. (1888). Selbstbeobachtung und innere Wahrnehmung. Philosophische Studien 4: 292309.

\section{Summary}

The Phenomenological Method in Museological Research The phenomenological method is closely associated with the study of human consciousness. In museum studies the phenomenological approach is essential for gaining an understanding of why museum collections are established and how they may influence the museum audience.

This article introduces the structure of human consciousness and the principles of the phenomenological method. The various stages of the phenomenological approach are put forward starting from an experiment carried out at the Art Museum in Esbjerg concerning how people are influenced by different kinds of introduction to art. Introspection and retrospection are first laid out as phenomenological strategies for observing what is going on within consciousness. Some of the major difficulties in studying the living stream of consciousness or an experience as it is later recalled in consciousness, are discussed. The following interview is defined as an explorative approach to a specific phenomenon. It is presented as a dialogue meant to inspire a person to describe the experience he or she has had and to make it possible for the researcher to grasp this experience through empathy. The aim of the final phenomenological description is to define the basic characteristics of the phenomenon in question. Epoché or phenomenological reduction is used in this context as a strategy for describing the phenomenon as it appears in consciousness, and the eidetic variation as a strategy for identifying the fundamental characteristics of the same phenomenon. Finally, the phenomenological description provides a basis for evaluating the influence of a specific phenomenon on human existence.

\section{Bjarne Sode Funch}

Ekstern lektor i personlighedspsykologi

Institut for Psykologi

Kobenhavns Universitet

E-mail:bjarne.funch@psy.ku.dk 
ARTIKLAR OM MUSEIPUBLIK OCH (KONST)UTSTÄLLNINGAR I TIDIGARE NUMMER AV Nordisk Museologi

\section{FURTHER READING ON SIMILAR SUBJECTS ALREADY PUBLISHED IN Nordisk Museologi}

$1993 / 1$

Erik Fischer, Kunstens museer, museernes kunst. Bjørnar Olsen, Det arkeologiske museum. Momenter til en kritikk.

$1993 / 2$

Boris Groys, The Logic of the Collection. $1994 / 1$

Walter Grasskamp, Reviewing the Museum - or: the Complexity of Things. $1994 / 2$

Heiner Treinen, Vad söker besökaren i museet? Inge Meldgaard, Fremtidens museumspædagogik - virkelighedsflugt eller forskningsformidling? Et forsvar for den empiriske publikumsforskning.

Anders Björnsson, Den rätta platsen. Några anteckningar om museer, medier och minnandet.

Janne Laursen, Museer og succes.

$$
1995 / 1
$$

John Millard, Art on Tyneside.

Birte Marie Løveid, Om strandvandringer og annen unyttig eksersis.

$$
1995 / 2
$$

Jette Sandahl, Proper objects among Other Things. Hans Pedersen, Beauty - Truth - Goodness. The Complex and Ambiguous Role of the Museum.

Göran Nylöf, An Increase in the Number of Visitors to Swedish Museums and Historical Sites.

$$
1996 / 1
$$

Peter Lewis, Unmixed Pleasure and Inward Doubts.

$$
1996 / 2
$$

Vibeke Petersen, Museet og kunstens iscenesættelse. Beate Sydhoff, Konstmuseet som metafor. $1997 / 1$

Angela Fussell, Make 'em laugh, make 'em cry! Collec- ting for Lifetimes, - the interactive museum about Croydon people.

Katja Lindqvist, Iscensättningens verklighet. Om Vera Frenkels installationer, några konstbyggen och museiutställningars historier.

$$
1998 / 1
$$

Susanna Pettersson, Public and Private: the Main Categories of Art Collection in Finland.

Camilla Mordhorst, Museumsgenstanden som relikvie. Ulla Wagner, Presenting "the Other" - Dilemmas for ethnographic museums.

\section{$1999 / 1$}

Peter Clarke, Developing audiences, developing learning: audience needs and the nature of learning. Helene Illeris, Four 14- and 15-year olds and a contemporary work of art.

Bruno Ingemann, "Det er helt vildt!" - om lesestrategier og reception af en udstilling.

$1992 / 2$

Chris Dercon, You can be a museum or you can be modern, but you can't be both.

Vibeke Petersen, Chris Dercon - en introduktion.

$$
\text { 2000/1 }
$$

Bjarne Sode Funch, Hvorfor ser vi på billedkunst?

Bruno Ingemann, Et menneske i oldtiden.

$$
\text { 2000/2 }
$$

Peter Ampt \& Linda Raymond, Culture denatured or Nature decultured?

Bjornar Olsen, Bilder fra fortida?

Camilla Gjendem, Kunstmuseets utstillingspraksis. 2001/1-2

Line Hjorth, Til minde om byen.

Elona Lubyte, About Strategies of Opening and Openness in Lithuanian Museology. 2002/1

Lennart Palmqvist, Utställningskonst i förändring. 2002/2

David Anderson, The Spiral as Concept and Metaphor. Jane Pavitt, Content and Display: Representing the Contemporary. 